Journal of Animal and Veterinary Advances 10 (14): 1855-1858, 2011

ISSN: $1680-5593$

(C) Medwell Journals, 2011

\title{
Polymorphism Analysis of the Horse Dopamine Receptor D4 Gene (DRD4) Sequence
}

\author{
${ }^{1}$ Caiyun Fan, ${ }^{2}$ Jianbo Cheng, ${ }^{3} \mathrm{Jinlian} \mathrm{Li}$, ${ }^{1}$ Qinghua Wang and ${ }^{4}$ Dugarjaviin Manglai \\ ${ }^{1}$ College of Animal Science, Henan Institute of Science and Technology, 453003 Xinxiang, P.R. China \\ ${ }^{2}$ College of Animal Science and Technology, Anhui Agricultural University, 230036 Hefei, P.R. China \\ ${ }^{3}$ Department of Biological Science and Technology, Taishan University, 271021 Tai' an, P.R. China \\ ${ }^{4}$ College of Animal Science and Technology, Inner Mongolia Agricultural University, \\ 010018 Hohhot, P.R. China
}

\begin{abstract}
In this study, partial sequence of horse $D R D 4$ gene was cloned including intron 1, partial exon 1 and exon 2. And restriction endonuclease Stu I was used to analyze the polymorphism of the $D R D 4$ gene sequences of 270 horses from six types including importing breed, cultivating breed and local breed. The products of endonuclease cutting were detected by $8 \%$ non-denatured polyacrylamide gel electrophoresis and showing in silver staining protocol. The result indicated restriction endonuclease Stu I showed polymorphism. Six kinds of genotypes were found in six populations which were controlled by three alleles. The results of Chi-square $\left(\chi^{2}\right)$ test showed that genotypes of horse DRD4 gene in TB, SH, XN did not fit with Hardy-Weinberg equilibrium $(\mathrm{p}<0.05)$ but in WS, BH and WZ fit with Hardy-Weinberg equilibrium ( $>0.05)$.
\end{abstract}

Key words: Horses, DRD4 gene, polymorphism, PCR-RFLP, silver staining, local bread, China

\section{INTRODUCTION}

Dopamine D4 Receptor (DRD4) is one of five member receptors known to function in mammalian dopaminergic pathways. DRD4 gene includes genetics order in junction and thus can control the brain to form ability of a certain receptor. These receptors are distributed on the surface of neuronal cells and can bind dopamine. It is well known that dopamine is a predominant catecholamine neurotransmitter in the mammalian brain where it controls a variety of functions including locomotor activity, cognition and emotion (Missale et al., 1998). In particular, DRD4 is the 1st gene that has been found to affect personality. For example, there is connection between the number of 48 base pair repeats in exon and Novelty Seeking (NS) personality trait (Benjamin et al., 1996).

The polymorphism of the $\mathrm{DRD} 4$ exon region has been reported in other mammalian species such as non-human primates, dogs and horses (Livak et al., 1995; Niimi et al., 1999, 2001; Hasegawa et al., 2002; Ito et al., 2004). The genetic polymorphism is proposed to be associated with human personality traits (Benjamin et al., 1996; Ebstein et al., 1996). In addition, polymorphisms have been discovered other regions of human and dog DRD4 gene which are thought to be associated with personality traits. The horse is one of the oldest domestic species. In the past, horse has been used so widely as communication, transport, agriculture progress and so on.
With the advent of science and technology however, the horse has lost its original use and is used primarily for recreational purposes today. Thus, improving breed characteristics for recreation purposes, i.e., selecting for personality traits will add tremendous economic value to existing breeds. The potential role of human DRD4 in personality traits has attracted considerable attention in recent years but not in horses. There are few studies on VNTR of $D R D 4$ gene exon III related to NS behavior in horses but other regions of horse DRD 4 gene have not been studied. The objective of this study was to analyze polymorphisms of the partial $D R D 4$ gene sequence among six types of horse.

\section{MATERIALS AND METHODS}

The peripheral blood samples of the Thoroughbred $(\mathrm{n}=50)$ were collected at the Huajun Stud Stable in Beijing. Blood samples were taken from Sanhe $(n=51)$, Xinihe $(\mathrm{n}=45)$ and Barhu (Baerhu) $(\mathrm{n}=54)$ horses in Hulunboir Aimag (Hulunbeier prefecture), Northeast of Inner Mongolia. Blood samples were collected from the Ujimchin (Wuzhumuqin) horse $(\mathrm{n}=40)$ in Shilingol Aimag (Xilinguole prefecture), Central Inner Mongolia whereas blood samples of Wushen horse $(n=30)$ were collected at Ordos area in western Inner Mongolia. Genomic DNA was isolated from each peripheral blood sample by using the phenol-choroform and proteinase $\mathrm{K}$ method. The

Corresponding Author: Dugarjaviin Manglai, College of Animal Science and Veterinary, Inner Mongolia Agricultural University, 010018 Hohhot, P.R. China 
DRD4 genotypes were analyzed using the PCR-RFLP method. The primers were designed based on the nucleotide sequence of human, mouse and ferret DRD4 gene. $5 \mathrm{FA}$ :

\section{Forward 5'-CTGCAGACGCCCACCAACT-3' Reverse 5'-TGGCGCACAGGTTGAAGAT-3'}

A 50 ng of template genomic DNA, 18 pmoles of each primer, $7.5 \mu \mathrm{L} 2 \times$ GC buffer II, $2.4 \mu \mathrm{L}$ dNTP $(2.5 \mathrm{Mm}$ each) and 0.75 units of LA Taq polymerase (Takara) were mixed in $15 \mu \mathrm{L}$ of reaction mixture. After initial incubation at $94^{\circ} \mathrm{C}$ for $5 \mathrm{~min}$, PCR amplification was performed for 35 cycles composed of denaturation at $94^{\circ} \mathrm{C}$ for $40 \mathrm{sec}$, annealing for $40 \mathrm{sec}$ and extension at $72^{\circ} \mathrm{C}$ for $40 \mathrm{sec} \sim 1 \mathrm{~min}$. This was followed by a final extension at $72^{\circ} \mathrm{C}$ for $7 \mathrm{~min}$. The PCR products were analyzed by electrophoresis in $1.2 \%$ agarose gel. The PCR products were digested with Stu I enzyme. Digestion products were separated electrophoretically in $8 \%$ nondenatured polyacrylamide gel electrophoresis $(\mathrm{Acr} / \mathrm{Bis}=29: 1,200 \mathrm{v}, 1.5 \sim 2.0 \mathrm{~h})$ and showing in silver staining protocol. Frequencies of distribution of alleles within the herds were compared with Chi-square $\left(\chi^{2}\right)$ test.

\section{RESULTS AND DISCUSSION}

Through primer pair 5FA, successfully amplified out the expected fragment containing intron I, partial exon I and II region of $D R D 4$ gene. The electrophoresis profiles are shown in Fig. 1. After PCR fragments were detection by PCR-RFLP method and sequencing, one SNP and one inserts/deletion were identified in intron I. Genotypes and allele of the $D R D 4$ gene are shown in Fig. 2. For the polymorphism, six genotypes and three alleles were distinguishable according to their restriction fragment lengths: 316,324 and $1121 \mathrm{bp}$ (A allele); 333, 324 and 1121 $\mathrm{bp}$ (B allele); 640 and $1121 \mathrm{bp}$ (C allele). By comparing the sequences of two types homozygote on SNP found that two sites showed nucleotide transition from A-G and insert/delete from $17 \mathrm{bps}$.

Statistical analysis of the site showed that dominant genotype and alleles of Thoroughbred are $\mathrm{AB}$ and $\mathrm{B}$ and dominant genotype and alleles of other breeds horse are $\mathrm{AA}$ and $\mathrm{A}$. The results of Chi-square $\left(\chi^{2}\right)$ test showed that genotypes of $D R D 4$ gene in $\mathrm{TB}, \mathrm{XN}$ and $\mathrm{SH}$ did not fit with Hardy-Weinberg equilibrium $(\mathrm{p}<0.01)$ but in $\mathrm{BH}$, WZ and WS, they did fit with Hardy-Weinberg equilibrium ( $\mathrm{p}>0.05$ ) (Table 1).

According to the breed history, the Sanhe horse is a locally-selected breed whereas the Thoroughbred is an imported breed. Their offspring breeding is mostly by

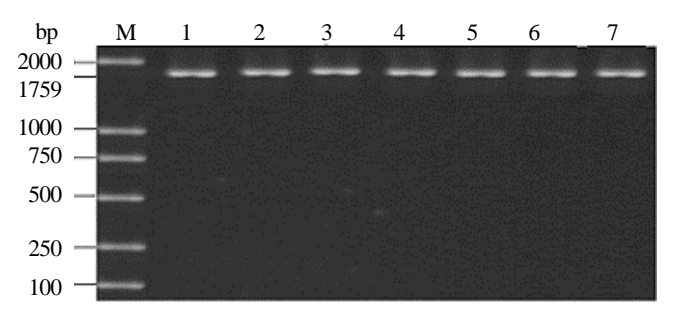

Fig. 1: Gel diagram of prolactin fragment amplified by primer pair 5FA before digestion

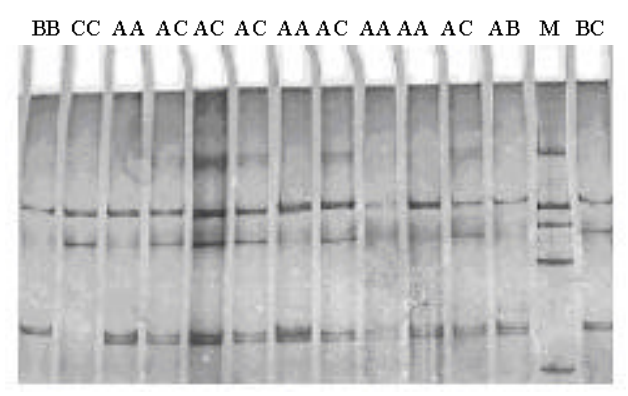

Fig. 2: Restriction analysis of DRD4 1759 bp PCR products digested with Stu I by $8 \%$ nondenatured polyacrylamide gel electrophoresis stained with silver M.DL2000 marker; $\mathrm{BB}$ genotype $=333,324$ and $1121 \mathrm{bp}$; $\mathrm{CC}$ genotype $=640$ and $1121 \mathrm{bp}$; $\mathrm{AA}$ genotype $=316,324 \mathrm{bp}, 1.121 \mathrm{~kb} ; \mathrm{AC}$ genotype $=$ 316 and $324 \mathrm{bp}, 1.121 \mathrm{~kb}, 639 \mathrm{bp} ; \mathrm{AB}$ genotype $=$ 316,324 and $333 \mathrm{bp}, 1.121 \mathrm{~kb}$; $\mathrm{BC}$ genotype $=333$ and $324 \mathrm{bp}, 1.121 \mathrm{~kb}, 639 \mathrm{bp}$

artificial selection. The artificial selection of offspring breeding is more rigorous in Thoroughbred than in others. This leads to disequilibrium of gene distribution. WS, XN, $\mathrm{WZ}$ and $\mathrm{BH}$ belong to different local populations of the Mongolian horse. These populations were bred in a relatively isolated natural environment.

Thus, the distribution of genes in these horses is close to equilibrium. The Xinihe horse is a local breed which is originated from the Northeastern Inner Mongolia (Hulunboir Aimag). The region is famous for horses for their speed and stamina because of a long history of breeding for races, including introduction of horses from other regions. Offspring breeding of Xinihe horse has artificial selection of a bigger ratio, so disequilibrium of gene distribution can also appear (Lai, 2003).

One SNPs $(1444 \mathrm{G} / \mathrm{A})$ and one insert/delete of the region have been found by polymorphism analysis of the sequence. These variations exist in Intron which do not lead to variation in amino acids. In humans, the variations in the intron regions are known to be associated with personality traits or psychiatric disorders such as the 
Table 1: Genotype distribution and allele frequencies at Stu I site of different breeds horse

\begin{tabular}{|c|c|c|c|c|c|c|c|c|c|c|c|}
\hline \multirow[b]{2}{*}{ Breed } & \multirow[b]{2}{*}{ Sample size } & \multicolumn{6}{|c|}{ Genotypes frequency } & \multicolumn{3}{|c|}{ Allele frequency } & \multirow[b]{2}{*}{$\left(\chi^{2}\right)(\mathrm{df})$} \\
\hline & & $\mathrm{AA}$ & $\mathrm{BB}$ & $\mathrm{CC}$ & $\mathrm{AB}$ & $\mathrm{AC}$ & $\mathrm{BC}$ & A & $\mathrm{B}$ & $\mathrm{C}$ & \\
\hline$\overline{\mathrm{XN}}$ & 45 & $\begin{array}{l}0.444 \\
(20)\end{array}$ & $\begin{array}{l}0.133 \\
\text { (6) }\end{array}$ & $\begin{array}{l}0.044 \\
\text { (2) }\end{array}$ & $\begin{array}{l}0.156 \\
\text { (7) }\end{array}$ & $\begin{array}{l}0.200 \\
(9)\end{array}$ & $\begin{array}{l}0.022 \\
\text { (1) }\end{array}$ & 0.622 & 0.222 & 0.156 & $11.39^{*}$ \\
\hline $\mathrm{BH}$ & 54 & $\begin{array}{l}0.370 \\
(20)\end{array}$ & $\begin{array}{l}0.130 \\
\text { (7) }\end{array}$ & $\begin{array}{l}0.056 \\
\text { (3) }\end{array}$ & $\begin{array}{l}0.296 \\
(16)\end{array}$ & $\begin{array}{l}0.130 \\
(7)\end{array}$ & $\begin{array}{l}0.019 \\
\text { (1) }\end{array}$ & 0.583 & 0.287 & 0.130 & 9.11 \\
\hline WZ & 40 & $\begin{array}{l}0.575 \\
(23)\end{array}$ & $\begin{array}{l}0.025 \\
\text { (1) }\end{array}$ & $\begin{array}{l}0.000 \\
(0)\end{array}$ & $\begin{array}{l}0.175 \\
\text { (7) }\end{array}$ & $\begin{array}{l}0.175 \\
(7)\end{array}$ & $\begin{array}{l}0.050 \\
\text { (2) }\end{array}$ & 0.750 & 0.138 & 0.112 & 1.26 \\
\hline ws & 30 & $\begin{array}{l}0.533 \\
(16)\end{array}$ & $\begin{array}{l}0.000 \\
(0)\end{array}$ & $\begin{array}{l}0.067 \\
\text { (2) }\end{array}$ & $\begin{array}{l}0.033 \\
\text { (1) }\end{array}$ & $\begin{array}{l}0.333 \\
(10)\end{array}$ & $\begin{array}{l}0.033 \\
\text { (1) }\end{array}$ & 0.717 & 0.033 & 0.250 & 0.75 \\
\hline SH & 51 & $\begin{array}{l}0.392 \\
(20)\end{array}$ & $\begin{array}{l}0.176 \\
\text { (9) }\end{array}$ & $\begin{array}{l}0.078 \\
\text { (4) }\end{array}$ & $\begin{array}{l}0.255 \\
(13)\end{array}$ & $\begin{array}{l}0.059 \\
\text { (3) }\end{array}$ & $\begin{array}{l}0.039 \\
\text { (2) }\end{array}$ & 0.549 & 0.324 & 0.127 & $21.05^{* * *}$ \\
\hline TB & 50 & $\begin{array}{l}0.040 \\
(2)\end{array}$ & $\begin{array}{l}0.280 \\
(14)\end{array}$ & $\begin{array}{l}0.100 \\
(5)\end{array}$ & $\begin{array}{l}0.420 \\
(21)\end{array}$ & $\begin{array}{l}0.020 \\
\text { (1) }\end{array}$ & $\begin{array}{l}0.140 \\
\text { (7) }\end{array}$ & 0.260 & 0.560 & 0.180 & $14.48^{\text {*** }}$ \\
\hline
\end{tabular}

$\mathrm{d}: \mathrm{df}=5, \chi^{2}(0.05)=11.07, \chi^{2}(0.01)=15.09$. *Means significant difference $(0.01<\mathrm{p}<0.05)$, ***Means most significant difference $(\mathrm{p}<0.01)$

association of the tryptophan hydroxylase gene intron VII with aggression in Schizophrenia and Schizoaffective disorders and the association of the serotonin transporter gene (5HHT) intron II with anxiety (Hong et al., 2001; Melke et al., 2001). In the case of DRD4, variation of a variable number of repeated $\mathrm{G}$ nucleotides in the intron I region has been reported although, it does not contribute to the susceptibility to Schizophrenia (Barr et al., 1993). In the neurotransmitter related genes, variation of a variable number of tandem repeat sequence such as the intron II region of human 5HTT has affected reporter gene expression (MacKenzie and Quinn, 1999). In Primates and $\mathrm{dog}$, the insert/deletion polymorphisms were found in the intron II. Insert/deletion of $17 \mathrm{bp}$ was found in the intron II region of dogs DRD4 gene and inserts/deletions of 6 and $8 \mathrm{bp}$ were found in intron II region of humans and apes DRD4 gene (Shimada et al., 2004; Hidetoshi et al., 2005). The polymorphisms do not relate to reporter gene expression.

So, further studies are required to determine the effect of variation in the horse DRD4 intron I region on reporter gene expression. Other associations between intronic variation and functional differences are possible. For example, alternative splicing such as the gene of Tau, a microtubule-associated protein or linkage with an exonic variant has been reported in DRD2 (O'Hara et al., 1993; Spillantini et al., 2000). Because, variation in the horse DRD4 intron I region was not linked with previously reported Exon polymorphic regions, this region can be an independent marker for the further survey of the relationship between genotype and horse behavioral traits. It can be postulated that the association between intronic variations and differences in behavioral trait is related to a change in Transcription Factor (TF) binding sites, alternative splicing and linkage with exonic variant (O'Hara et al., 1993; Fiskerstrand et al., 1999; Spillantini et al., 2000). In order to elucidate the mechanism of these associations, expression analysis may be effective because variations in intron II region of humans and apes DRD4 gene can lead to changes in TF binding sites (Shimada et al., 2004). In humans after DRD4 gene was cloned in 1991, some genetic markers associated with personality were identified which have become the basis for investigating DRD4 gene in other mammals (Van Tol et al., 1991).

Would there be some associations between these polymorphisms in horse DRD4 gene and personality? It still requires more data on the sequence variations of this gene with a greater number of individuals for each breed in the future.

\section{CONCLUSION}

The present study is the 1st report to examine the polymorphisms of DRD4 in the Mongolia horse with the sequence compared with other species. We found some novel polymorphisms using RFLP among six breeds including a total of 270 individuals. Thus, the analysis of these polymorphisms in DRD 4 gene is a useful means for the studies of evolution and behavior sciences.

\section{ACKNOWLEDGMENTS}

The researchers are grateful for the support of Henan Institute of Science and Technology Startup Foundation for Doctor (No. 7014), Anhui Provincial Natural Science Foundation (No. 090411019) and the National Natural Science Foundation of China (307601 62). Caiyun Fan and Jianbo Cheng contributed equally to this work.

\section{REFERENCES}

Barr, C.L., J.L. Kennedy, J.B. Lichter, H.H. van Tol, L. Wetterberg, K.J. Livak and K.K. Kidd, 1993. Alleles at the dopamine D4 receptor locus do not contribute to the genetic susceptibility to schizophrenia in a large Swedish kindred. Am. J. Med. Genet., 48: 218-222. 
Benjamin, J., L. Li, C. Patterson, B.D. Greenberg, D.L. Murphy and D.H. Hamer, 1996. Population and familial association between the D4 dopamine receptor gene and measures of Novelty Seeking. Nat. Genet., 12: 81-84.

Ebstein, R.P., O. Novick, R. Umansky, B. Priel and Y. Osher et al., 1996. Dopamine D4 receptor (D4DR) exon III polymorphism associated with the human personality trait of Novelty Seeking. Nat. Genet., 12: $78-80$.

Fiskerstrand, C.E., E.A. Lovejoy and J.P. Quinn, 1999. An intronic polymorphic domain often associated with susceptibility to affective disorders has allele dependent differential enhancer activity in embryonic stem cells. FEBS Lett., 458: 171-174.

Hasegawa, T, F. Sato and N. Ishida, 2002. Determination and variability of nucleotide sequences for D4 dopamine receptor genes (DRD4) in genus equus. J. Equine Sci., 13: 57-62.

Hidetoshi, N., I.M. Miho, K. Akiko, S. Akinori and M. Yuichi et al., 2005. Novel polymorphism of the canine dopamine receptor D4 gene intron II region. Anim. Sci. J., 76: 81-86.

Hong, C.J., S.J. Tsai and Y.C. Wang, 2001. Association between tryptophan hydroxylase gene polymorphism (A218C) and schizophrenic disorders. Schizophrenia Res., 49: 59-63.

Ito, H., H. Nara, M. Inoue-Murayama, M.K. Shimada and A. Koshimura et al., 2004. Allele frequency distribution of the canine dopamine receptor D4 gene exon III and I in 23 breeds. J. Vet. Med. Sci., 66: $815-820$.

Lai, M., 2003. Animal Quantitative Genetics. Inner Mongolia Agriculture University, Hohhot, China.

Livak, K.J., J. Rogers and J.B. Lichter, 1995. Variability of dopamine D4 receptor (DRD4) gene sequence within and among nonhuman primate species. Proc. Natl. Acad. Sci. USA., 92: 427-431.
MacKenzie, A. and J. Quinn, 1999. A serotonin transporter gene intron 2 polymorphic region, correlated with affective disorders, has alleledependent differential enhancer-like properties in the mouse embryo. Proc. Natl. Acad. Sci. USA., 96: 15251-15255.

Melke, J., M. Landen, F. Baghei, R. Rosmond and G. Holm et al., 2001. Serotonin transporter gene polymorphisms are associated with anxiety-related personality traits in women. Am. J. Med. Genet., 105: 458-463.

Missale, C., S.R. Nash, S.W. Robinson, M. Jaber and M.G. Caron, 1998. Dopamine receptors: From structure to function. Physiol. Rev., 78: 189-225.

Niimi, Y., M. Inoue-Murayama, K. Kato, N. Matsuura and Y. Murayama et al., 2001. Breed differences in allele frequency of the dopamine receptor D4 gene in dogs. J. Heredity, 92: 433-436.

Niimi, Y., M. Inoue-Murayama, Y. Murayama, S. Ito and T. Iwasaki, 1999. Allelic variation of the D4 dopamine receptor polymorphic region in two dog breeds, Golden retriever and Shiba. J. Vet. Med. Sci., 61: 1281-1286.

O'Hara, B.F., S.S. Smith, G. Bird, A.M. Persico, B.K. Suarez, G.R. Cutting and G.R. Uhl, 1993. Dopamine D2 receptor RFLPs, haplotypes and their association with substance use in black and Caucasian research volunteers. Hum. Heredity, 43: 209-218.

Shimada, M.K., M. Inoue-Murayama, Y. Ueda, M. Maejima and Y. Murayama et al., 2004. Polymorphism in the second intron of dopamine receptor D4 gene in humans and apes. Biochem. Biophys. Res. Commun., 316: 1186-1190.

Spillantini, M.G., J.C. van Swieten and M. Goedert, 2000. Tau gene mutations in frontotemporal dementia and parkinsonism linked to chromosome 17 (FTDP-17). Neurogenetics, 2: 193-205.

Van Tol, H.H.M., J.R. Bunzow, H.C. Guan, R.K. Sunahara, P. Seeman, H.B. Niznik and O. Civelli, 1991. Cloning of the gene for a human dopamine D4 receptor with high affinity for the antipsychotic clozapine. Nature, 350: 610-614. 